\title{
The Role of Art Therapy in Eating Disorder Advocacy
}

\author{
Article \\ Art Therapy: Journal of the American Art Therapy Association \\ Special Issue: Client Voices \\ ARTTHERAPY-D-19-00046
}

Word Count: 4382 (2 figures)

This is the author's manuscript of the article published in final edited form as:

Misluk-Gervase, E. (2020). The Role of Art Therapy in Eating Disorder Advocacy. Art Therapy, 1-7. https://doi.org/10.1080/07421656.2020.1823783 


\begin{abstract}
Art therapy group can facilitate professional and self advocacy efforts to increase awareness of eating disorders. Imagine Me Beyond What You See art competition was the catalyst for the development of an art therapy group to raise awareness for eating disorders and body image by reimagining a mannequin. Participant testimonials demonstrate how this process impacted recovery and empowered clients to become advocates in their communities.
\end{abstract}

Keywords: art therapy, advocacy, eating disorders, mannequin, body

This is the author's manuscript of the article published in final edited form as:

Misluk-Gervase, E. (2020). The Role of Art Therapy in Eating Disorder Advocacy. Art Therapy, 1-7. https://doi.org/10.1080/07421656.2020.1823783 


\section{The Role of Art Therapy in Eating Disorder Advocacy}

When Audre Lorde, American writer, poet, feminist, and civil rights activist (1984) stated, "I have come to believe over and over again that what is most important to me must be spoken, made verbal and shared, even at the risk of having it bruised or misunderstood," she captured the experience, both empowering and fear inducing that is generated when an individual engages in advocacy (p. 40). Advocacy, the act of supporting a cause or policy by influencing the decision makers or changing the balance of power (Jussessur \& Iles, 2009), can take several forms. This article describes an integration of advocacy with art therapy for clients living with eating disorders.

\section{Advocacy in Mental Health Settings}

Advocacy in the field of mental health should be at the core because of the understanding that clients need more than therapists can provide in face-to-face sessions (Toporek, et al., 2009). Within mental health, advocacy includes actions taken by allies (professional advocacy) or affected individuals (self-advocacy). Professional advocacy is the empowerment of clients and their families on goals related to mental health, wellness, education and occupation (ACA, 2018). These efforts include: educating families and communities on mental health issues, trying to persuade insurance companies to provide coverage for treatment options, and petitioning lawmakers to address issues related to access to quality treatment, research funding, and treating mental health as a public health issue. Mental health workers are urged to advocate in an effort to combat social injustices that impact all aspects of clients' lives (Donald \& Moro, 2014; Ratts, 2009). Some examples include: joining national organizations, collaborating with peers to write letters, attending advocacy days on Capitol Hill, and working with lawmakers to draft bills that

This is the author's manuscript of the article published in final edited form as:

Misluk-Gervase, E. (2020). The Role of Art Therapy in Eating Disorder Advocacy. Art Therapy, 1-7. https://doi.org/10.1080/07421656.2020.1823783 
support clinical concerns. The overarching goal of these professional advocacy efforts is the promotion of well-being for individuals, groups, and organizations with the aim to remove "barriers and obstacles that inhibit access and/or growth and development of clients" (American Counseling Association, 2014, p.5). As a result, clinicians, clients, families, and friends join together to amplify the individual voice to affect change.

Although professional testimony and allyship is crucial, the most powerful voices in advocacy work are not those of the practioners or the families, but those who have the lived experience of an issue. Self-advocacy requires that individuals know and value themselves, assert their rights, express their needs (Jussessur \& Iles, 2009), assume personal responsibility, and take positive action to challenge a societal status (Williams \& Schoultz, 1982). Perhaps most importantly, self-advocacy requires that individuals are capable of building an empowered mindset (Goodley, 1997). Mental health clinicians can support clients in developing these skills and abilities by identifying strengths, illuminating external barriers, and exploring client responses to systemic issues (Donald \& Moro, 2014; Jussessur \& Iles, 2009). Through the development of self-advocacy skills and action plans, clients can experience empowerment within the therapeutic setting.

For some, the way to share this experience may come in the form of speaking at national events. In 2018, Shalini Wickramatilake, an advocate in recovery, spoke at the National Eating Disorders Association (NEDA) Walk in Washington, DC and recounted her experience of selfadvocacy:

As I stood before a crowd of people speaking my truth, sharing my story, and even crying on stage, I felt something that has made my motivation for recovery higher than it's ever

This is the author's manuscript of the article published in final edited form as:

Misluk-Gervase, E. (2020). The Role of Art Therapy in Eating Disorder Advocacy. Art Therapy, 1-7. https://doi.org/10.1080/07421656.2020.1823783 
been: empowered. I felt empowered as I owned my struggle. I felt empowered as I vulnerably shed tears in front of hundreds of strangers. I felt empowered as those incredibly kind strangers embraced me and thanked me for sharing my story. I felt empowered because on that day, for the first time I believed that I truly was in recovery, not forever doomed to be teetering between health and illness (para 4-5). For others though, it is through visual representations, not spoken word, that they are best able to express themselves and recount their individual and collective experiences as they work toward healing. "Artmaking lends itself to collaborative activity because it is often used to identify issues and solution" (Spaniol, 2005, p. 87). An example of arts-based advocacy, the NAMES Project served as both a therapeutic and political tool by providing individuals with HIV and AIDS, family, friends, and communities impacted by the disease a creative space to document and display their experiences. Cleve Jones, the founder of the NAMES Project, chose the quilt motif to be the medium through which to communicate his message because of its historical significance in breaking down barriers, increasing inclusivity, and promoting integration (Lewis \& Fraser, 1996). The quilt provided the medium to challenge mainstream perspectives and conceptualizations, while promoting social activism and health promotion. Arts advocacy is about "the artistry of social consciousness grounded in human interaction" that uses public spaces to address issues of social, political, and cultural importance (Frostig, 2011, p.51). Art therapists are uniquely positioned to participate in arts-based advocacy by focusing on the creative abilities and mental health needs of our clients (Spaniol, 1990).

\section{Media and Body Image}

In the United States of America, people of all social and ethics groups and particularly

This is the author's manuscript of the article published in final edited form as:

Misluk-Gervase, E. (2020). The Role of Art Therapy in Eating Disorder Advocacy. Art Therapy, 1-7. https://doi.org/10.1080/07421656.2020.1823783 
women, are inundated by images of what constitutes beauty, including size and weight and the perception of these on wealth, worth, education, and health (Taylor, 2018). As a result, perpetuated societal rules for attaining the ideal body contribute to misinformation about weightrelated illness and death (Campos, 2004). Rules include food restriction and harmful exercise patterns coupled with phrases that vilify food and our relationship to it (e.g., cheat days, indulgences, food rewards, being bad) when eating foods that are deemed "unhealthy" by cultural standards (Tovar, 2018). Examples of these rules in media that reflect incultural standards are television shows like The Biggest Loser, Extreme Weight Loss, Revenge Body, and Extreme Makeover. The messages underlying these highly successful shows are very clear: Americans should feel shame about their bodies and it is only through achieving physical change through unhealthy measures, such as food restriction and extreme physical activity, that they can shed that shame and feel worth by being deemed attractive by society.

Store mannequins market clothes by showing how flattering they are when worn by someone with the ideal body further contributing to body image distortion. An individual might be able to limit consumption of online images geared towards diet plans, exercise programs, and clothing to "fix" whatever part of the body is problematic. However, a store that sells clothing for all sizes typically places the notably fewer clothing options for larger bodies along with its few plus-sized mannequins (usually a size 8) towards the back of the store in relation to the front entrance (Dixon, 2019). By doing this, retailers communicate to $80 \%$ of the population who do not have the ideal body that their bodies are not meant to be seen or acknowledged (Campos, 2004).

The recent body positive movement has started to challenge society's fatphobia and fat-

This is the author's manuscript of the article published in final edited form as:

Misluk-Gervase, E. (2020). The Role of Art Therapy in Eating Disorder Advocacy. Art Therapy, 1-7. https://doi.org/10.1080/07421656.2020.1823783 
shaming culture (Taylor, 2018). This movement has resulted in positive results, such as a greater representation of mannequins and integration of clothing sections. For example, in 2019, Nike challenged the perspective that health is determined by size. In the London store, Nike included a mannequin size 16-18 to market athletic clothing. This decision elicited both praise and contention, as it directly conflicted with medical, pharmaceutical, diet, and cosmetic industries that are financially dependent on fat-shaming (Campos, 2004, 2019).

\section{Imagine Me Art Therapy Groups}

To illustrate a way to integrate advocacy and art therapy, the International Association of Eating Disorder Professionals (IAEDP; 2019) Imagine Me Beyond What You See art competition "was designed to promote a healthy awareness and acceptance of body images" and encouraged art therapists to collaborate with individuals with eating disorders to reimagine the body (para. 1). It provided a platform to share stories of the individual and collective experience of the body, eating disorders, and journeys towards recovery (http://www.iaedp.com/imagine-me/). In the same way that the NAMES Project allowed for a creative space to document a specific experience, this forum fostered an opportunity to use a mannequin as the foundation of the art making to challenge cultural and societal notions of the ideal body, while also increasing awareness and educating others on eating disorders.

The guidelines for the art competition allowed individual and group submissions from art therapists working with individuals with eating disorders. The submitted mannequins and their corresponding written descriptions were compiled and a voting link was released to the public. This gave the participants an opportunity to share the survey link through email and social media, thereby allowing them to build awareness of eating disorders through their personal,

This is the author's manuscript of the article published in final edited form as:

Misluk-Gervase, E. (2020). The Role of Art Therapy in Eating Disorder Advocacy. Art Therapy, 1-7. https://doi.org/10.1080/07421656.2020.1823783 
professional, and social connections. The voting link allowed the general public to select their favorite mannequin and to learn more about eating disorders on the main IAEDP webpage. Social media enabled participants' communities to grow through reposting, retweeting, or forwarded email links, thus exposing the competition, research, and treatment trends to larger and potentially more diverse groups of people. Additionally, attendees of the IAEDP annual symposium were permitted to vote and the winners of the contest were announced at a special recognition event.

I promoted the Imagine Me Beyond What You See Art Therapy Group at a small private practice where I worked with a psychologist and dietitian exclusively with individuals with eating disorders. Flyers were placed in the waiting room and discussed with interested participants. The group was offered free of charge so that financial need was not a deterrent to participation. The group centered on the creation of a mannequin and discussions related to messages about beauty, size, and worth received from influential sources including family, friends, religious and cultural organizations, and social media.

The selection of a mannequin that reflected a more realistic version of the female body proved to be very challenging. After reaching out to several major retailers in an urban Midwestern city for a donation, it was stated that they did not display full body "plus-sized" mannequins. Plus-sized retailers were then contacted, and no stores had a full body mannequin that they were able to donate. Through an online search, Iwas able to purchase a full body plussized mannequin who fit the criteria for a size 8 . It is important to note that this was the only plus-sized mannequin available from this retailer, and it came with permanent high heels. This search exposed just how limited the number of mannequins is that represent a wide variety of

This is the author's manuscript of the article published in final edited form as:

Misluk-Gervase, E. (2020). The Role of Art Therapy in Eating Disorder Advocacy. Art Therapy, 1-7. https://doi.org/10.1080/07421656.2020.1823783 
sizes, shapes, and heights. This process reinforced ideas of cultural and societal control on the types of bodies valued.

\section{Art Examples}

The following section discusses the development of the initial group and the adaptions to the group that was offered the following year. As a result, each group created a mannequin for the Imagine Me Beyond What You See art competition. The goals for the groups were to provide a structured space, a range of supplies, and reflective questions that would support the participants in the development of a mannequin that reflected their story and experience. It also provides a context for using art therapy in advocacy efforts.

\section{Group 1: Nancy}

Group One consisted of four self-identified White cisgender women, ages 20-40, with different diagnostic and treatment profiles who were at varying stages of eating disorder recovery. The group named their white fiberglass mannequin Nancy. Before Nancy could be transformed by the creative process, each member of the group was prompted to think about impactful messages they received about body image throughout their life. They explored and discussed how those messages affected their eating disorder and recovery process. I guided them to conceptualize how those messages and consequential experiences have shaped their understanding of the self in the world, and how those experiences could be articulated into a single concept for the mannequin. The resounding theme that emerged from the journaling was the concepts of And and Or This results in rigid thought patterns that support the continued behaviors of the eating disorder. For example:

I am happy if I am thin. If I am not thin than I am not happy. In order to be happy I must

This is the author's manuscript of the article published in final edited form as:

Misluk-Gervase, E. (2020). The Role of Art Therapy in Eating Disorder Advocacy. Art Therapy, 1-7. https://doi.org/10.1080/07421656.2020.1823783 
engage in restriction and over-exercising to be thin so I can be happy. I cannot be happy

AND eat. I am fat if I eat. So I must make the decision to be happy OR to eat.

In the process of recovery understanding these messages are a necessary part of the treatment process.

Moving into the creative process, the participants were concerned with "ruining" the mannequin and expressed feelings of self-doubt, perfectionism, and disappointment. In the third session, the group took turns using a pencil to begin to create areas of separation on the mannequin for each individual to design. They transposed their narrative into their selfdesignated sections. At their request, they used the following materials: acrylic paint, glitter, gems, and natural materials (dirt, mulch, moss, leaves). During the fourth session, I encouraged the participants to discuss the separate designs by asking, "What do you notice? What visually interests you?" As a result of this discussion, the participants made connections among their separate narratives. This observation prompted them to work within one another's space, explore how it feels to make similar marks and creative elements of other participants, ask for one another's feedback, and negotiate future decisions. At the end of week four, the group had not yet completed work on Nancy. Therefore, the group was extended for one final session to add final creative elements and develop their description for the competition.

The group titled Nancy, Embarking on a Lifelong Journey (Figure 1), and wrote the following description:

Through the exploration of mind, body, and soul to examine the personal and collective experiences of self in the world, the transformation of the mannequin began. The lines and ideas that once seemed separate and different became the lines that

This is the author's manuscript of the article published in final edited form as:

Misluk-Gervase, E. (2020). The Role of Art Therapy in Eating Disorder Advocacy. Art Therapy, 1-7. https://doi.org/10.1080/07421656.2020.1823783 
intertwine to form a cohesive statement of discovery and acceptance.

With this integration, the mannequin is filled with different lines, colors, layers, and textures that tell her story, a story where she once felt bound. Through the recognition of the strength that she has always possessed, she breaks away from the societal expectations that try to keep her still; these binds cannot compare to her internal power. It is her strength that motivates her to take her first step, taking with her the lessons that she has learned.

As she leaves the darkness of the woods behind her, searching for something more promising, she does not try to deny the existence of her struggles, but rather weaves them into her being...

For moss cannot grow on the rolling stone, she continues to move forward, carrying with her the leaves of experience, wisdom, lessons, and strength that she has gathered; embarking on a lifelong journey that began with a single step.

Embarking on a Lifelong Journey received the most votes at the 2016 annual symposium and was awarded the "Professional's Choice" award. Additionally, this artwork was displayed at the Indiana chapter of the National Eating Disorder Association NEDA Walk, which raises awareness and funding for eating disorder treatment and research. This display provided an opportunity to advocate by educating attendees, local businesses and organizations on art therapy and the benefits for individuals with eating disorders.

\section{Group 2: Bernadette}

For the second group the next year, a grant was awarded through the Eating Disorder Task Force of Indiana to help procure the cost of a mannequin and supplies. This group consisted

This is the author's manuscript of the article published in final edited form as:

Misluk-Gervase, E. (2020). The Role of Art Therapy in Eating Disorder Advocacy. Art Therapy, 1-7. https://doi.org/10.1080/07421656.2020.1823783 
of two previous participants and two new members. They all self-identified as White cisgender women age 20-40 with different diagnostic and treatment profiles who were at varying stages of eating disorder recovery. The group structure was consisted with the first one but met weekly for five weeks based on the timeline extension of the previous group.

The selection of the mannequin proved to be challenging. The mannequin used previously was the only plus-sized one available, which forced the group to use a standard one. Since there were repeat participants, consideration was given to exploring a different body position which could potentially elicit a different story or message.. Bernadette, as the group called her, was a size 2 seated black fiberglass mannequin. At the onset, the group discussed the size and shape of the mannequin and the effect of this body ideal within the group.

Iprovided several options for the focus of this mannequin and the group selected the following poem by Amanda Lovelace (2017):

if you ever

look at

your reflection

$\&$ feel the desire

to tell yourself

you're not

good enough, beautiful enough, skinny enough, curvy enough,

This is the author's manuscript of the article published in final edited form as:

Misluk-Gervase, E. (2020). The Role of Art Therapy in Eating Disorder Advocacy. Art Therapy, 1-7. https://doi.org/10.1080/07421656.2020.1823783 
then $\mathrm{i}$ think

it's about time

you smashed that mirror to bits,

don't you?

- use those fragments to make stepping-stones to your own self-love (p. 175)

I read the poem aloud during the first group and provided copies for each participant.

They reflected upon this poem through journaling with a focus on self-love. Through discussion, they decided that mosaics would best visually represent the deconstruction to reconstruction of self-love. The two previous participants took an active role in guiding the process from conception to completion demonstrating the skills needed for self-advocacy including expressing their needs, assuming responsibility, and taking positive action. The group used glass and stone tile, tissue paper, magazines, mod podge, acrylic paint, and fabric.

In the second session, the participants used painter's tape to section off areas of the mannequin, discussed tiles and color schemes, and delegated tasks. They openly discussed the process, gained insight from one another, brainstormed materials to use in each area, and worked collaboratively on larger sections throughout the remaining sessions. In the final session, the group added a mirror to reflect multiple perspectives of Bernadette to the viewer. They also wrapped sheer fabric behind her lower back and draped over her legs for additional texture and dimension. These additional elements supported the goal of the mannequin reflecting the concept of being “piece of many.” They titled her, Fragments to Make Stepping Stones (Figure 2), and wrote the following description:

Seated in a pose of confidence and strength; fragments of tile, stone, mirror, and paper

This is the author's manuscript of the article published in final edited form as:

Misluk-Gervase, E. (2020). The Role of Art Therapy in Eating Disorder Advocacy. Art Therapy, 1-7. https://doi.org/10.1080/07421656.2020.1823783 
join to show she is more than her reflection. She is more than a singular material but pieces of many. Fragments within fragments and details within details, reflect the complexity of the self- discovery. Only those willing to get close enough to see the details within the whole understand this journey. Shattering the mirror exposed the myriad of the self, challenging the misconception that we are one single story, one material, and one experience.

At the 2017 IAEDP annual symposium, Fragments to Make Stepping Stones was awarded Runner Up upon receiving the second most votes from the national voting process. Additionally, both Embarking on a Lifelong Journey and Fragments to Make Stepping Stones were displayed at Herron School of Art and Design, IUPUI during the Indiana University Board of Trustees annual meeting. This provided a platform to educate higher level administration about eating disorders and an opportunity to advocate on behalf of art therapy and eating disorder professional communities.

\section{Participant Reflections}

The foundation of advocacy has three components: know yourself, know your needs, and know how to get your needs met. After the completion of the group, participants were asked to provide a testimonial about their experience in the group. These testimonials served to inform me about the individual impact of the group and the experience of creating a collaborative art piece that would be used towards advocacy efforts.

A participant who collaborated on Embarking on a Lifelong Journey demonstrated that she gained a deeper awareness of self and the impact of the group on her self-esteem, body acceptance, and perspective. She was also able to identify what her needs were including

This is the author's manuscript of the article published in final edited form as:

Misluk-Gervase, E. (2020). The Role of Art Therapy in Eating Disorder Advocacy. Art Therapy, 1-7. https://doi.org/10.1080/07421656.2020.1823783 
listening to her own voice and adopting a kind and positive mindset. In her testimonial, she wrote:

I became so fearful of my body and hated how I looked on the outside. I let all around me affect who I was and how I acted. Looking back I was in a state of almost being disgusted with it.articipating in the project opened my eyes to see how negative I used to be.This opened my eyes to truly appreciate what our bodies do for us...I would have worked to love my body instead of shame it, I would have tried to build up strength too instead of constantly telling myself I was ugly, I would not have listened to everyone else but myself. This process and experience taught me how truly important our bodies are for us.This, process in all was, emotional, healing, a learning process about ourselves; it helped me grow and heal in countless ways.

A participant in both Imagine Me groups expressed that the groups helped her gain deeper knowledge of self, notice awareness of her growth throughout the process, and identify her need to challenge thought processes rooted in her eating disorder. She also explored the impact that her experience had on her larger community in the following testimonial:

Working on the mannequins was a very cathartic experience for me, but also presented several challenges. It was difficult for me to give up the sense of control I wanted to have over the project.... Ultimately, I wanted the mannequins to still be aesthetically pleasing, but that's also something that the project was forcing us to question. Who gets to decide what is desirable and where do those notions come from? Do we truly believe these certain traits are beautiful, or is it just what we are told? What is pretty or pleasing to one, could create stress in another... I think

This is the author's manuscript of the article published in final edited form as:

Misluk-Gervase, E. (2020). The Role of Art Therapy in Eating Disorder Advocacy. Art Therapy, 1-7. https://doi.org/10.1080/07421656.2020.1823783 
Bernadette was much more representative of different aspects of recovery and the different ways we process the messages of beauty. I absolutely think that these projects help with advocacy. The more I learn about eating disorders, the more aware I am of the messages I'm sending and receiving...it also gives me the opportunity to provide education, share my story, and advocate for change to be made so people understand how damaging the messages of weight loss and weight control can truly be.

Both participants were able to demonstrate that this project increased the advocacy goal of know yourself and know your needs. Neither participant included information that discussed knowing how to get those needs met though resources outside of the therapeutic environment. This indicates that it may be beneficial for future groups to identify resources for increased selfadvocacy efforts.

\section{Conclusion}

The group targeted a small population of individuals with little variance in demographic profile. A wider demographic of participations would have enhanced the groups experience of eating disorder experiences and perspectives on advocacy. In turn, the mannequin and accompanying message may have reached a broader and more diverse audience. Many of the participants had an existing therapeutic relationship with me and participated in both groups. This may have increased the impact of this project. It reduced the amount of time spent building rapport and the participants were accustomed to art therapy and art making a the primary mode of self-discovery. Additionally, the majority of participants had all engaged in group therapy prior to this group and were aware of group rules and norms.

Through the Imagine Me groups, clients were empowered to advocate for themselves

This is the author's manuscript of the article published in final edited form as:

Misluk-Gervase, E. (2020). The Role of Art Therapy in Eating Disorder Advocacy. Art Therapy, 1-7. https://doi.org/10.1080/07421656.2020.1823783 
through community collaboration and educating the public. The groups served as a space where participants identified their strengths and discussed the social, political, economic, and cultural influences on body image, weight, and health, as well as, challenged one another on thoughts and behaviors that were incongruent with their recovery. The competition allowed for public dissemination of eating disorder information, eating related concerns, and body image issues. Sharing the voting link increased self-advocacy skills and engaged the extended communities of all competition participants. The community engagements and collaborations that evolved as a result of the groups and competition demonstrate a way to integrate advocacy into art therapy.

\section{Acknowledgement}

The author would like to thank all participants and those individuals who provided testimonials included in this article.

\section{References}

American Counseling Association, (2014). 2014 ACA code of ethics. https://www.counseling.org/resources/aca-code-of-ethics.pdf

American Counseling Association, (2018). American Counseling Association advocacy competencies. https:/www.counseling.org/docs/default-source/competencies/aca-2018advocacy-competencies.pdf

Campos, P. (2004). The obesity myth: Why America's obsession with weight is hazardous to your health. New York, NY: Gotham.

Dixon, E. (2019, June 6). Nike introduces plus-size mannequins to London store. CNN.https://www.cnn.com/style/article/london-nike-mannequins-scli-intl/index.html

Donald, E. J., \& Moro, R. R. (2014). Engaging students and supervisees in social justice: The

This is the author's manuscript of the article published in final edited form as:

Misluk-Gervase, E. (2020). The Role of Art Therapy in Eating Disorder Advocacy. Art Therapy, 1-7. https://doi.org/10.1080/07421656.2020.1823783 
social justice toolbox. Ideas and Research You Can Use: VISTAS. 1-16. https://www.counseling.org/docs/defaultsource/vistas/article_10.pdf?sfvrsn=1c003afc_12

Frostig, K. (2011). Arts activism: Praxis in social justice, critical discourse, and radical modes of engagement. Art Therapy: Journal of the American Art Therapy Association, 28(2), 5056. https://doi.org/10.1080/07421656.2011.578028

Goodley, D. (1997). Locating self-advocacy in models of disability: Understanding disability in the support of self-advocates with leaning difficulties. Disability and Society, 12, 367379. https://doi.org/10.1080/09687599727227

Lewis, J., \& Fraser, M. (1996). Patches of grief and rage: Visitor responses to the NAMES Project AIDS Memorial Quilt. Qualitative Sociology, 19(4), 433-451. https://doi.org/10.1007/BF02393368

Lorde, A. (1984). Sister outsider: Essays and speeches by Audre Lorde. Trumansburg, NY: The Crossing Press.

Lovelace, A. (2017). The princess saves herself in this one. Kansas City, MO: Andrew McMeel. Ratts, M. J. (2009). Social justice counseling: Toward the development of a fifth force among counseling paradigms. Journal of Humanistic Counseling, Education and Development, 48(2), 160-172. https://doi.org/10.1002/j.2161-1939.2009.tb00076.x

Spaniol, S. E. (1990). Exhibiting art by people with mental illness: Issues, process and principles. Art Therapy, 7(2), 70-78. https://doi.org/10.1080/07421656.1990.10758896

Spaniol, S. (2005). "Learned hopefulness": An arts-based approach to participatory action research. Art Therapy: Journal of the American Art Therapy Association, 22(2), 86-91. https://doi.org/10.1080/07421656.2005.10129446

This is the author's manuscript of the article published in final edited form as:

Misluk-Gervase, E. (2020). The Role of Art Therapy in Eating Disorder Advocacy. Art Therapy, 1-7. https://doi.org/10.1080/07421656.2020.1823783 
Taylor, S. R. (2018). The body is not an apology: The power of radical self-love. Oakland, CA: Berrett-Koehler.

The International Association of Eating Disorder Professionals Foundation. (2019). Imagine me. http://www.iaedp.com/imagine-me/

The NAMES Project Foundation. (2019). The AIDS Memorial Quilt.https://www.aidsquilt.org/about/the-aids-memorial-quilt

Toporek, R. L., Lewis, J. A., \& Crethar, H. C. (2009). Promoting systemic change through the aca advocacy competencies. Journal of Counseling \& Development, 87(3), 260-268. https://doi.org/10.1002/j.1556-6678.2009.tb00105.x

Tovar, V. (2018). You have the right to remain fat. New York, NY: Feminist Press.

Wickramatilake, S. (2018). A milestone in my recovery. The National Eating Disorder Assocation.https://www.nationaleatingdisorders.org/blog/speaking-dc-neda-walk$\underline{\text { milestone-my-recovery }}$

Williams, P.\& Schoultz B. (1982). We can speak for ourselves: Self-advocacy by mentally handicapped people. Bloomington, IN: Indiana University Press.

This is the author's manuscript of the article published in final edited form as: 


\section{List of Figures}

Figure 1. Nancy

Figure 2. Bernadette

This is the author's manuscript of the article published in final edited form as:

Misluk-Gervase, E. (2020). The Role of Art Therapy in Eating Disorder Advocacy. Art Therapy, 1-7. https://doi.org/10.1080/07421656.2020.1823783 